Supporting Information

\title{
Noncubic to Cubic Structural Transformation in Au Microcrystallites by Oxidative Etching
}

\author{
Chaitali Sow and Giridhar U. Kulkarni*
}

Chemistry and Physics of Materials Unit, Jawaharlal Nehru Centre for Advanced Scientific

Research (JNCASR), Bengaluru 560064, India

Email: kulkarni@jncasr.ac.in

\section{Calculation of structure factor:}

Structure factor for fcc, $F_{h k l}=f\left(1+e^{\pi i(h+k)}+e^{\pi i(k+l)}+e^{\pi i(h+l)}\right)$

Structure factor for body-centered lattice, $F_{h k l}=f\left(1+e^{\pi i(h+k+l)}\right)$

Intensity of the XRD peaks, I $=\mathrm{F}_{\mathrm{hkl}}^{2}$

The allowed reflections in fcc are (111) and (200); and $\mathrm{I}_{\mathrm{fcc}}=\mathrm{F}_{\mathrm{hkl}}^{2}=16 \mathrm{f}^{2}$.

Similarly, the allowed reflections in body-centered lattices are (101), (011), (110), (002); and, $\mathrm{I}_{\mathrm{bc}(\mathrm{o}, \mathrm{t})}=\mathrm{F}_{\mathrm{hkl}}^{2}=4 \mathrm{f}^{2}$.

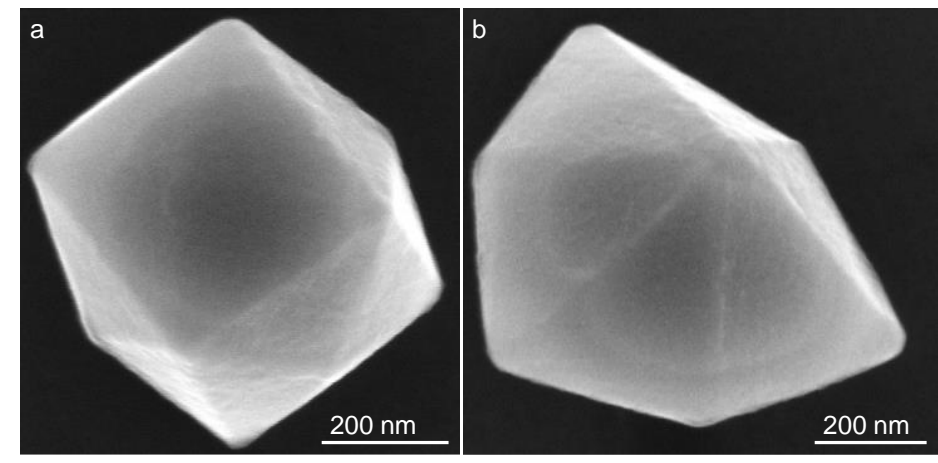

Figure S1. (a,b) SEM images of tetrahexahedral and hexagram shaped microcrystallites, respectively synthesized along with the Au bipyramids as side products. 

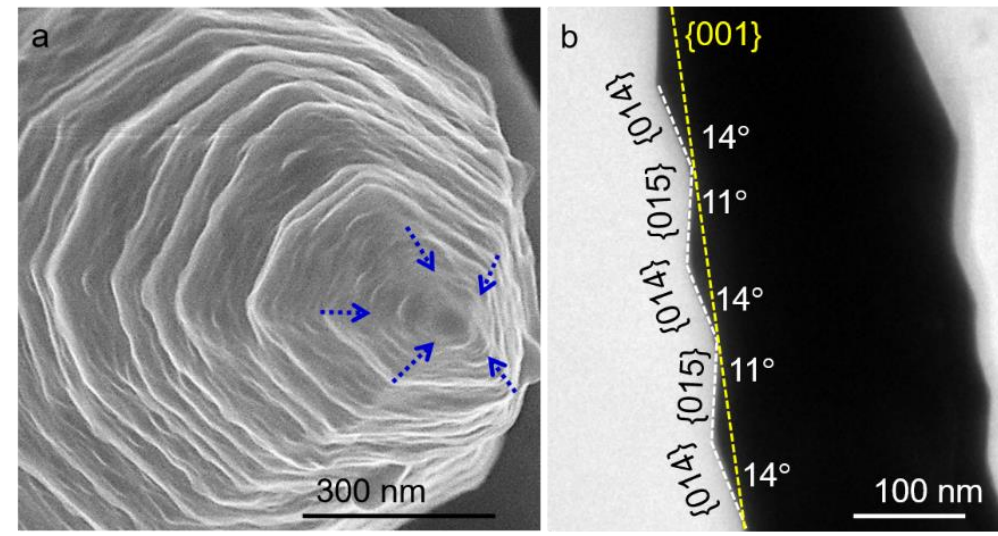

Figure S2. (a) SEM image of the penta-twinned tip. The five twin boundaries shown by the blue dotted arrows. (b) Magnified TEM image of a Au bipyramid showing high index facets.

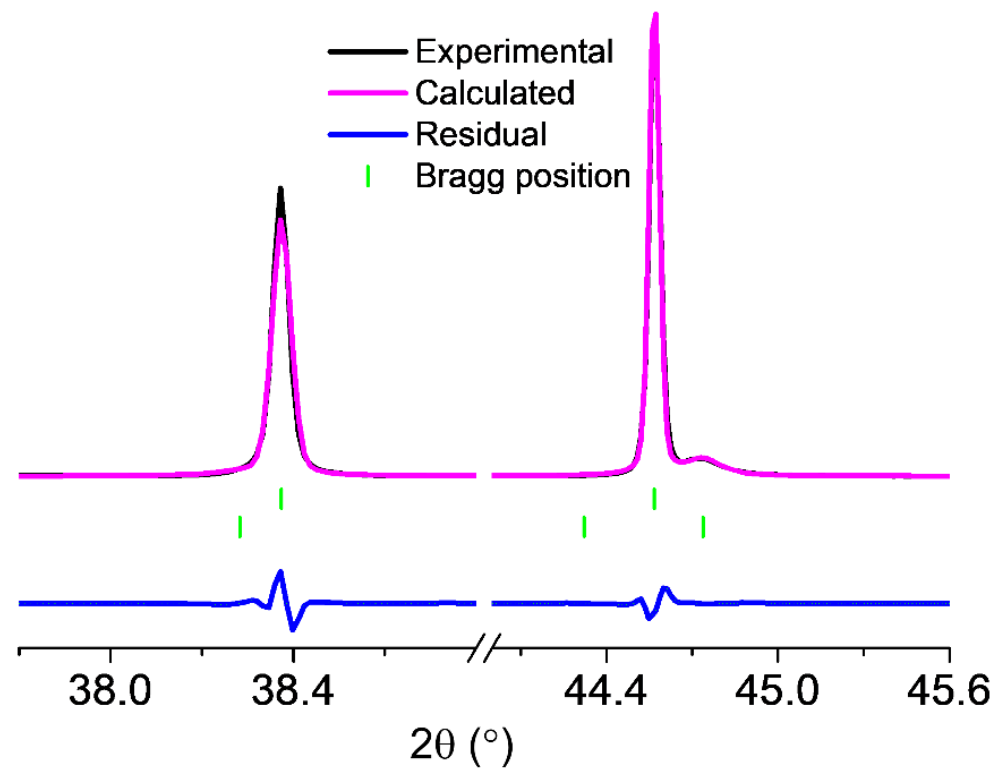

Figure S3. Le Bail fitting of the XRD data collected from $\mathrm{N}\left(\mathrm{C}_{4}\right)_{4}{ }^{+}$treated Au microcrystallites (at $\left.220^{\circ} \mathrm{C}\right)$. 

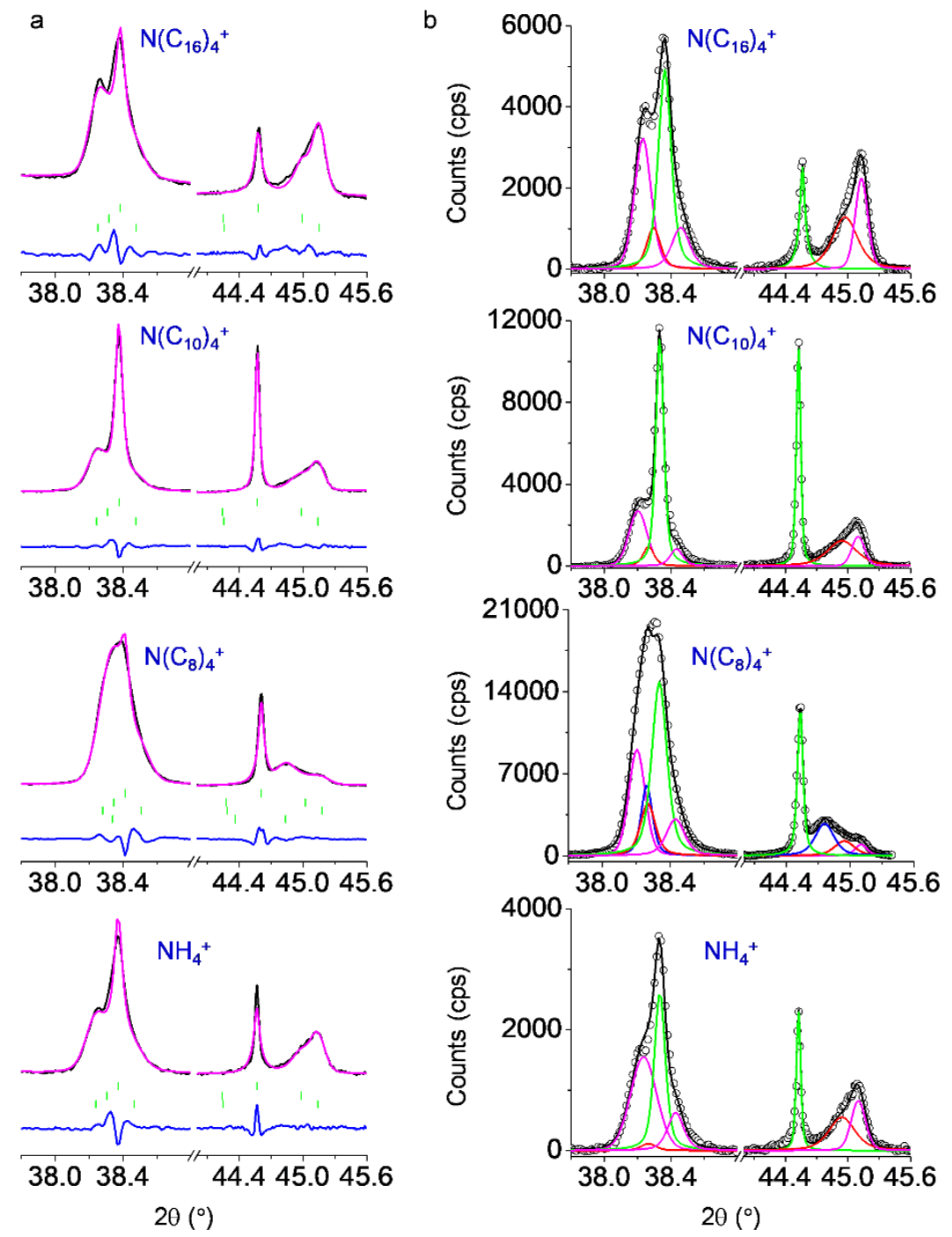

Figure S4. (a) Le Bail fitting of the XRD data collected from Au microcrystallites treated with various adsorbents. Black, pink, blue and green color curves indicate the experimental, calculated, residual (experimental-calculated) and Bragg position, respectively. (b) Profile matching of the XRD patterns collected post-treatment with quaternary ammonium salts at $220{ }^{\circ} \mathrm{C}$ for $7 \mathrm{~min}$. The black circles represent the experimental data. The green, red, pink and blue are the contributions from fcc, bct, bco and bct-I, respectively and their sum is shown in black color curve. The bct-I contributes toward $\mathrm{N}\left(\mathrm{C}_{8}\right){ }_{4}{ }^{+}$only. 


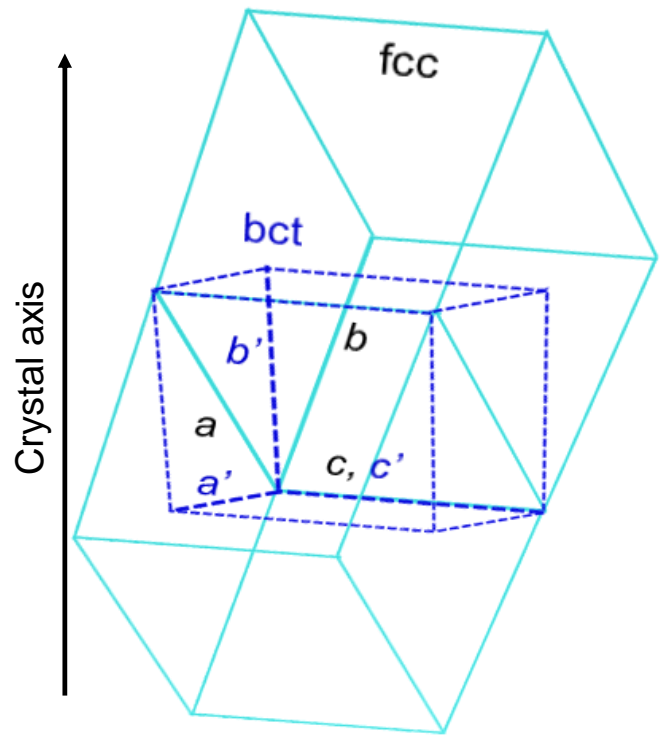

Figure S5. A bct unit cell is borne out of two face-shared fcc unit cells.
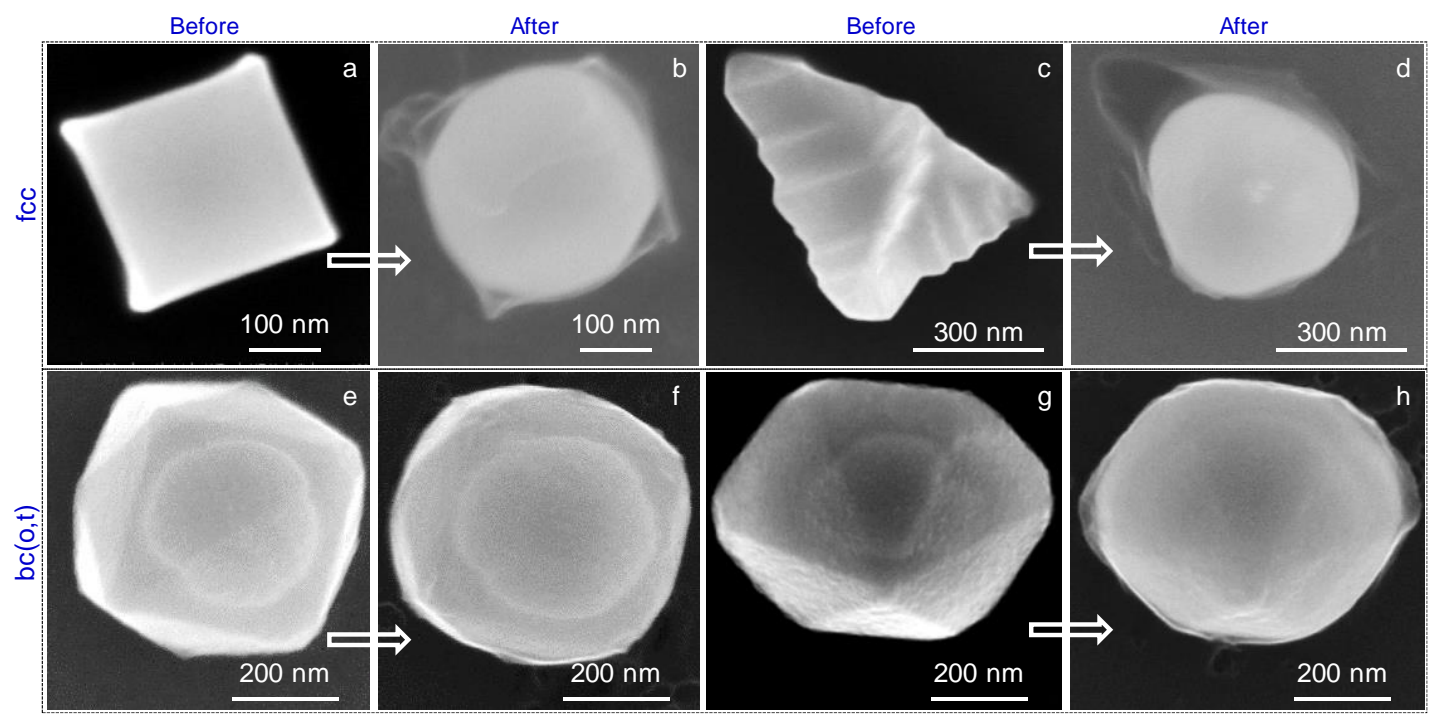

Figure S6. Effect of $\mathrm{N}\left(\mathrm{C}_{4}\right)_{4}{ }^{+}$treatment on the morphology of the $\mathrm{Au}$ microcrystallites. SEM images of pristine fcc $(\mathrm{a}, \mathrm{c})$ and $\mathrm{bc}(\mathrm{o}, \mathrm{t})(\mathrm{e}, \mathrm{g})$ microcrystallites and their corresponding images at the post-treatment with $\mathrm{N}\left(\mathrm{C}_{4}\right)_{4}{ }^{+}$in $(\mathrm{b}, \mathrm{d})$ and $(\mathrm{f}, \mathrm{h})$, respectively. The arrow shows the post-treatment effect. The as-synthesized sharper corners, edges and vertexes disappear and become nearly round in shape. The rounding effect is more prominent in the top panel with sharper corners and edges while being independent on the exposed facets. Thus, the change in morphology is governed by the curvature of the crystallite surface and not by the pristine crystal structure. 


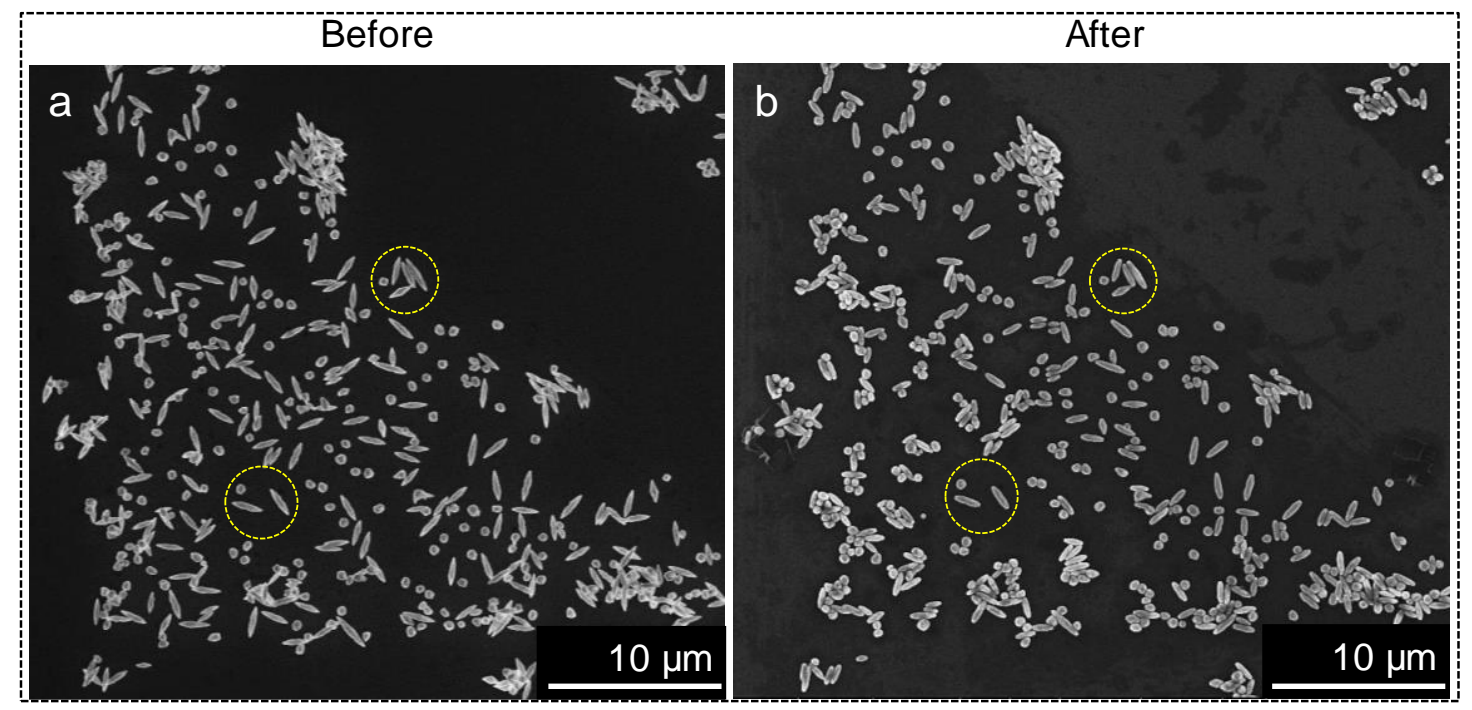

Figure S7. Large area view of the $\mathrm{N}\left(\mathrm{C}_{4}\right)_{4}{ }^{+}$treated crystallites. SEM images of the microcrystallites (a) before and (b) after $\mathrm{N}\left(\mathrm{C}_{4}\right)_{4}{ }^{+}$treatment at $220^{\circ} \mathrm{C}$ for $7 \mathrm{~min}$. The yellow circles have been drawn for reference. During the adsorbent treatment, the crystallites are locally immobile and thus allow to monitor the changes in the morphology of the same crystallite. No additional formation of the particulates observed in (b).
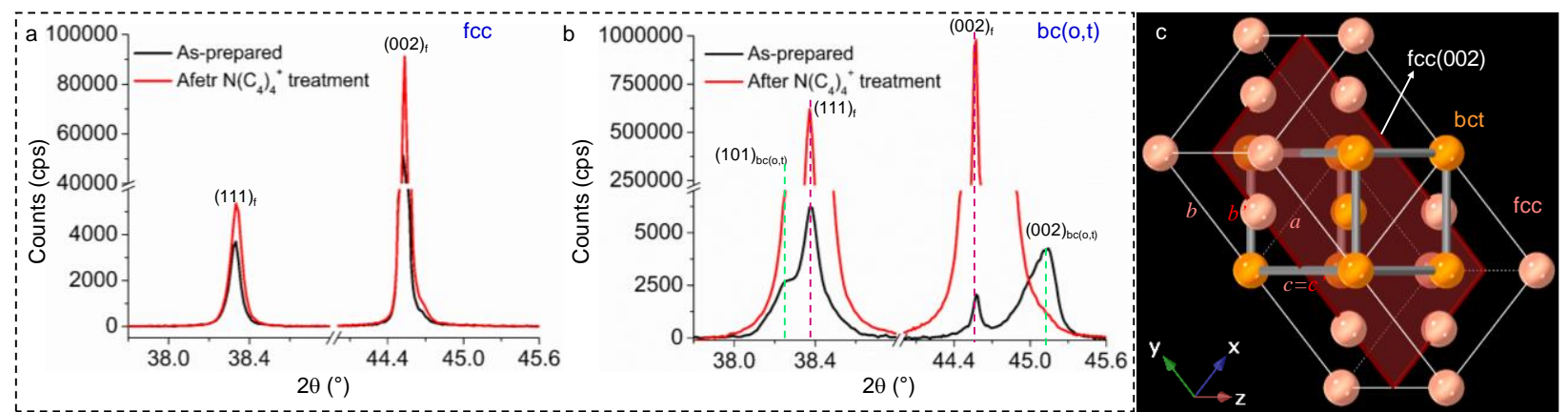

Figure S8. Effect of $\mathrm{N}\left(\mathrm{C}_{4}\right)_{4}{ }^{+}$treatment on the XRD pattern. Changes in the XRD patterns of (a) fcc and (b) bc(o,t) crystallites before and after $\mathrm{N}\left(\mathrm{C}_{4}\right)_{4}{ }^{+}$treatment at $220{ }^{\circ} \mathrm{C}$ for $7 \mathrm{~min}$. The treated XRD patterns exhibit an overall increment in the intensities highlighting enhancement in crystallinity in both the cases, however, the astonishing enhancement observed by 493 times for $(002)_{b c(o, t)}$. (c) Schematic illustration of a bct lattice borne out of two face-shared fcc unit cells. $x$, $\mathrm{y}$ and $\mathrm{z}$ axes present the $a, b$ and $c$ axes of fcc cell, respectively. $a^{\prime}, b^{\prime}$ and $c^{\prime}$ are axes of bct cell. Both the $c$ and $c$ ' axes coincide and lye in the horizontal plane, while the $a$ and $b$ axes of the fcc are rotated by $45^{\circ}$ with respect to the bct $a^{\prime}$ and $b^{\prime}$ axes. The orange atoms connected by the solid 
thicker lines represent the bct cell, derived from fcc. The $(002)_{\mathrm{T}}$ plane coincides with the $(002)_{\mathrm{f}}$ plane.

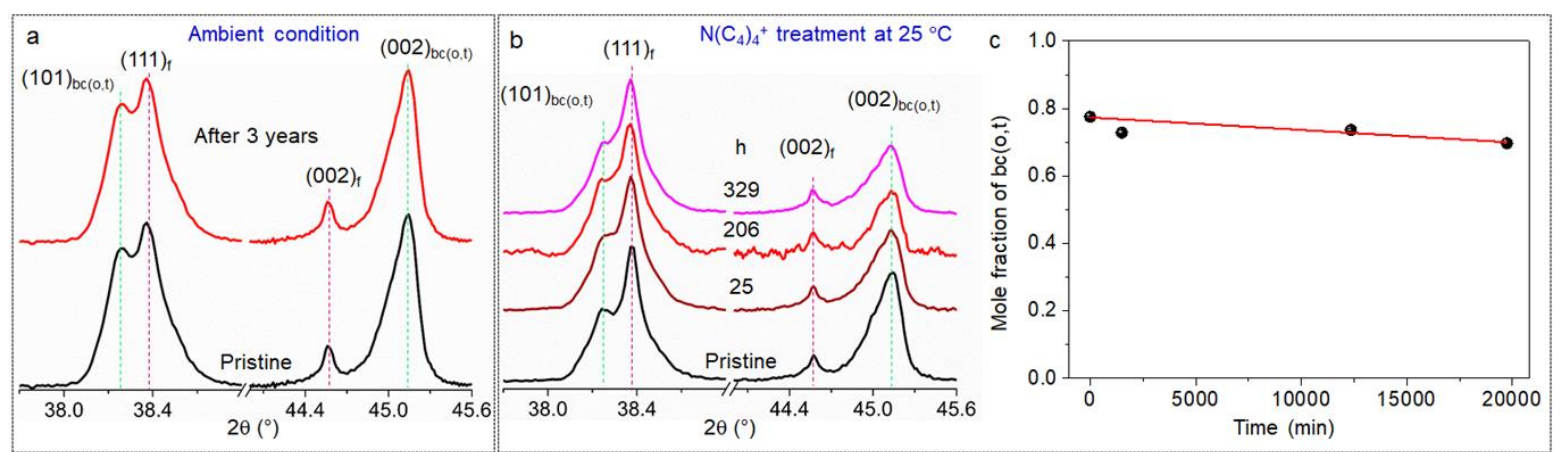

Figure S9. Stability of bc(o,t) Au microcrystallites studied at $25^{\circ} \mathrm{C}$ at different environments, (a) ambient condition and $(b, c)$ in $\mathrm{N}\left(\mathrm{C}_{4}\right)_{4}{ }^{+}$solution by monitoring changes in XRD patterns. The composition of the phases remain intact at ambient condition, while a gradual reduction in the mole fraction of the $b c(o, t)$ phases as shown in $(c)$, indicating phase transformation to fcc induced by the adsorbent. 


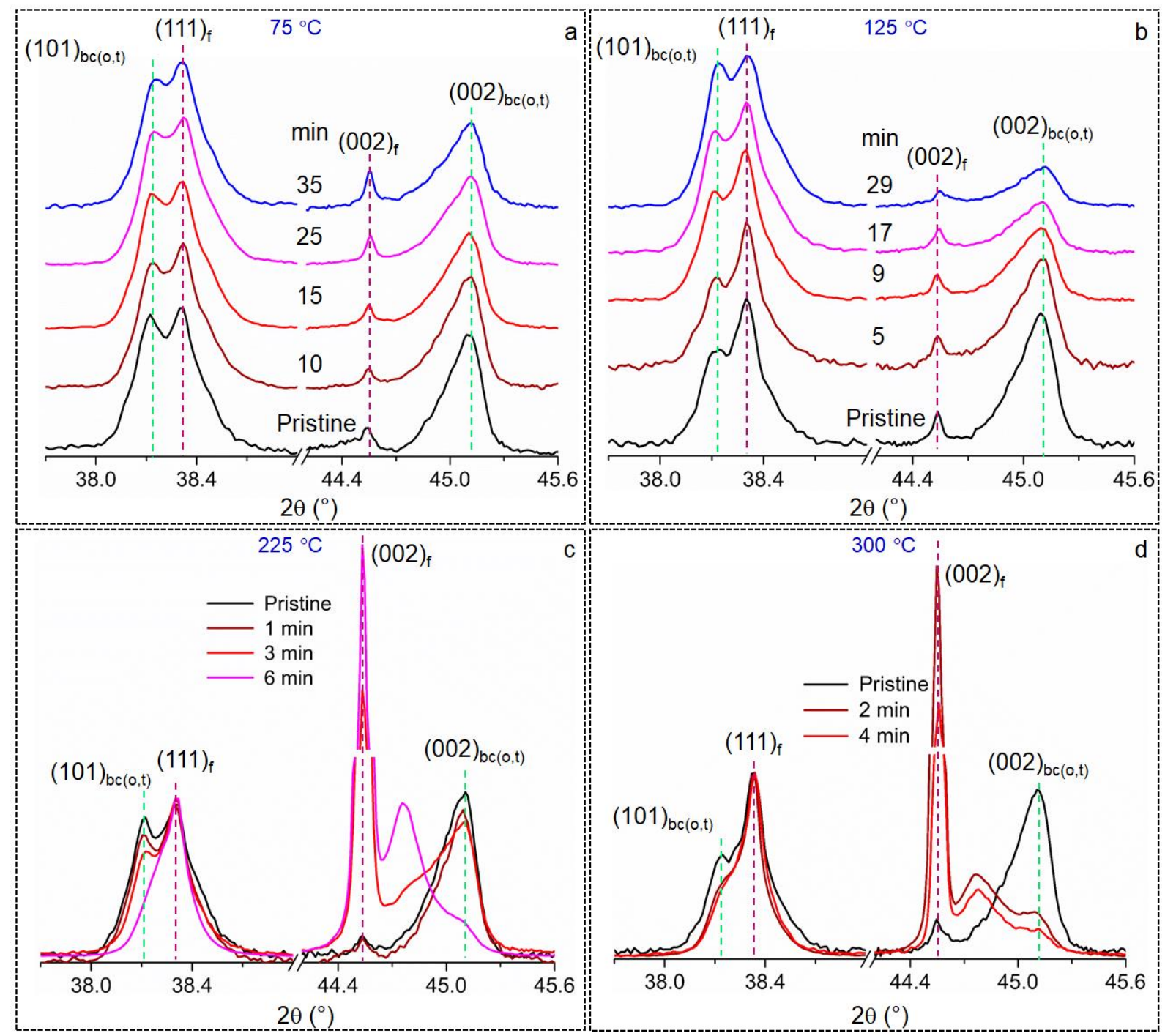

Figure S10. Temperature dependent $\mathrm{N}\left(\mathrm{C}_{4}\right)_{4}{ }^{+}$treatment on bc(o,t) Au microcrystallites. (a-d) Time dependent changes in the XRD pattern has been monitored by XRD for $75,125,225$ and $300{ }^{\circ} \mathrm{C}$, respectively. From the variation in the area under the peak, mole fraction of $b c(o, t)$ have been calculated and plotted in Figure 4b. 


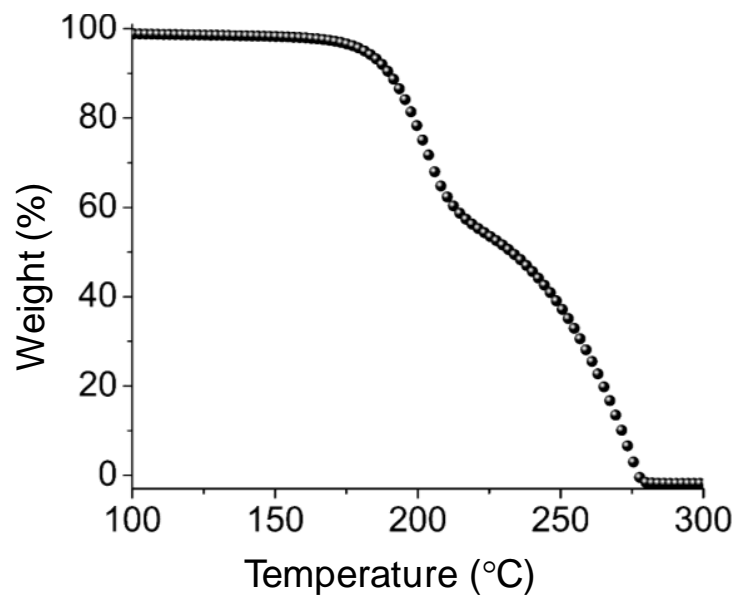

Figure S11. Thermogravimetric analysis (TGA) of tetrabutylammonium bromide at $\mathrm{N}_{2}$ environment. The decomposition is very fast at $\sim 220^{\circ} \mathrm{C}$. 
Table S1. Lattice parameter details.

\begin{tabular}{|c|c|c|c|c|c|c|c|c|c|c|c|c|}
\hline \multirow{2}{*}{$\begin{array}{l}\text { Quaternary } \\
\text { ammonium } \\
\text { cations }\end{array}$} & \multirow{2}{*}{$\begin{array}{c}\text { fcc } \\
a=b \\
=c(\AA)\end{array}$} & \multicolumn{3}{|c|}{ bct } & \multicolumn{5}{|c|}{ bco } & \multicolumn{3}{|c|}{ bct-I } \\
\hline & & $a=b(\AA)$ & $c(\AA)$ & $c / a$ & $a(\AA)$ & $b(\AA)$ & $c(\AA)$ & $c / a$ & $c / b$ & $a=b(\AA)$ & $c(\AA)$ & $c / a$ \\
\hline $\mathrm{NH}_{4}{ }^{+}$ & 4.0810 & $\begin{array}{c}2.9060 \pm \\
0.0001\end{array}$ & $\begin{array}{c}4.0451 \pm \\
0.0001\end{array}$ & $\begin{array}{c}1.3919 \pm \\
0.0000\end{array}$ & $\begin{array}{c}2.9178 \pm \\
0.0005\end{array}$ & $\begin{array}{c}2.8934 \pm \\
0.0002\end{array}$ & $\begin{array}{c}4.0315 \pm \\
0.0000\end{array}$ & $\begin{array}{c}1.3816 \pm \\
0.0000\end{array}$ & $\begin{array}{c}1.3933 \pm \\
0.0001\end{array}$ & - & - & - \\
\hline $\mathrm{N}\left(\mathrm{C}_{4}\right)_{4}{ }^{+}$ & 4.0810 & - & - & - & - & - & - & - & - & $\begin{array}{c}2.9004 \pm \\
0.0005\end{array}$ & $\begin{array}{c}4.0662 \pm \\
0.0000\end{array}$ & $\begin{array}{c}1.4019 \pm \\
0.0002\end{array}$ \\
\hline $\mathrm{N}\left(\mathrm{C}_{8}\right)_{4}{ }^{+}$ & 4.0810 & $\begin{array}{c}2.9055 \pm \\
0.0009\end{array}$ & $\begin{array}{c}4.0461 \pm \\
0.0012\end{array}$ & $\begin{array}{c}1.3925 \pm \\
0.0006\end{array}$ & $\begin{array}{c}2.9182 \pm \\
0.0002\end{array}$ & $\begin{array}{c}2.8932 \pm \\
0.0002\end{array}$ & $\begin{array}{c}4.0315 \pm \\
0.0018\end{array}$ & $\begin{array}{c}1.3814 \pm \\
0.0005\end{array}$ & $\begin{array}{c}1.3934 \pm \\
0.0005\end{array}$ & $\begin{array}{c}2.9012 \pm \\
0.0002\end{array}$ & $\begin{array}{c}4.0615 \pm \\
0.0006\end{array}$ & $\begin{array}{c}1.3999 \pm \\
0.0002\end{array}$ \\
\hline$N\left(C_{10}\right) 4^{+}$ & 4.0810 & $\begin{array}{c}2.9061 \pm \\
0.0000\end{array}$ & $\begin{array}{c}4.0455 \pm \\
0.0000\end{array}$ & $\begin{array}{c}1.3920 \pm \\
0.0001\end{array}$ & $\begin{array}{c}2.9176 \pm \\
0.0005\end{array}$ & $\begin{array}{c}2.8933 \pm \\
0.0006\end{array}$ & $\begin{array}{c}4.0316 \pm \\
0.0001\end{array}$ & $\begin{array}{c}1.3818 \pm \\
0.0002\end{array}$ & $\begin{array}{c}1.3934 \pm \\
0.0003\end{array}$ & - & - & - \\
\hline $\mathrm{N}\left(\mathrm{C}_{16}\right) 4^{+}$ & 4.0810 & $\begin{array}{c}2.9062 \pm \\
0.0002\end{array}$ & $\begin{array}{c}4.0453 \pm \\
0.0003\end{array}$ & $\begin{array}{c}1.3919 \pm \\
0.0000\end{array}$ & $\begin{array}{c}2.9174 \pm \\
0.0000\end{array}$ & $\begin{array}{c}2.8939 \pm \\
0.0007\end{array}$ & $\begin{array}{c}4.0317 \pm \\
0.0002\end{array}$ & $\begin{array}{c}1.3819 \pm \\
0.0000\end{array}$ & $\begin{array}{c}1.3931 \pm \\
0.0003\end{array}$ & - & - & - \\
\hline
\end{tabular}


Table S2. Variation in the lattice parameters of the $\mathrm{N}\left(\mathrm{C}_{4}\right)_{4}{ }^{+}$treated Au microcrystallites in bco, bct and bct-I unit cells.

\begin{tabular}{|c|c|c|c|c|c|}
\hline $\begin{array}{c}\text { Treatment } \\
\text { temperature }\left({ }^{\circ} \mathrm{C}\right)\end{array}$ & Time & $\begin{array}{l}\text { bct } \\
(c / a)\end{array}$ & $\begin{array}{l}\text { bco } \\
(c / a)\end{array}$ & $\begin{array}{l}\text { bco } \\
(c / b)\end{array}$ & $\begin{array}{l}\text { bct-I } \\
\text { (c/a) }\end{array}$ \\
\hline \multirow{3}{*}{25} & $25 \mathrm{~h}$ & $1.3919 \pm 0.0000$ & $1.3816 \pm 0.0001$ & $1.3936 \pm 0.0001$ & - \\
\hline & $206 \mathrm{~h}$ & $1.3910 \pm 0.0007$ & $1.3816 \pm 0.0001$ & $1.3931 \pm 0.0002$ & - \\
\hline & $329 \mathrm{~h}$ & $1.3919 \pm 0.0000$ & $1.3816 \pm 0.0001$ & $1.3935 \pm 0.0000$ & - \\
\hline \multirow{5}{*}{75} & $10 \mathrm{~min}$ & $1.3918 \pm 0.0000$ & $1.3815 \pm 0.0001$ & $1.3935 \pm 0.0000$ & - \\
\hline & $15 \mathrm{~min}$ & $1.3918 \pm 0.0000$ & $1.3815 \pm 0.0001$ & $1.3935 \pm 0.0000$ & - \\
\hline & $25 \mathrm{~min}$ & $1.3918 \pm 0.0006$ & $1.3815 \pm 0.0000$ & $1.3934 \pm 0.0000$ & - \\
\hline & $35 \mathrm{~min}$ & $1.3918 \pm 0.0000$ & $1.3816 \pm 0.0002$ & $1.3935 \pm 0.0001$ & - \\
\hline & $56 \mathrm{~min}$ & $1.3919 \pm 0.0000$ & $1.3817 \pm 0.0002$ & $1.3934 \pm 0.0000$ & - \\
\hline \multirow{4}{*}{125} & $5 \mathrm{~min}$ & $1.3918 \pm 0.0000$ & $1.3817 \pm 0.0002$ & $1.3934 \pm 0.0000$ & - \\
\hline & $9 \min$ & $1.3918 \pm 0.0000$ & $1.3816 \pm 0.0002$ & $1.3934 \pm 0.0000$ & - \\
\hline & $17 \min$ & $1.3918 \pm 0.0000$ & $1.3816 \pm 0.0002$ & $1.3935 \pm 0.0000$ & - \\
\hline & $29 \min$ & $1.3918 \pm 0.0000$ & $1.3816 \pm 0.0001$ & $1.3935 \pm 0.0000$ & - \\
\hline \multirow{4}{*}{180} & $5 \mathrm{~min}$ & $1.3919 \pm 0.0000$ & $1.3817 \pm 0.0002$ & $1.3932 \pm 0.0002$ & - \\
\hline & $14 \mathrm{~min}$ & $1.3919 \pm 0.0000$ & $1.3817 \pm 0.0002$ & $1.3932 \pm 0.0002$ & $1.4015 \pm 0.0013$ \\
\hline & $25 \mathrm{~min}$ & $1.3917 \pm 0.0001$ & $1.3814 \pm 0.0000$ & $1.392 \pm 0.0007$ & $1.3967 \pm 0.0028$ \\
\hline & $45 \mathrm{~min}$ & $1.3932 \pm 0.0012$ & - & - & $1.4001 \pm 0.0002$ \\
\hline
\end{tabular}




\begin{tabular}{|c|c|c|c|c|c|}
\hline $\begin{array}{c}\text { Treatment } \\
\text { temperature }\left({ }^{\circ} \mathbf{C}\right)\end{array}$ & Time & $\begin{array}{c}\text { bct } \\
(\boldsymbol{c} / \mathbf{a})\end{array}$ & $\begin{array}{c}\text { bco } \\
(\boldsymbol{c} / \mathbf{a})\end{array}$ & $\begin{array}{c}\text { bco } \\
(\boldsymbol{c} / \mathbf{b})\end{array}$ & $\begin{array}{c}\text { bct-I } \\
(\boldsymbol{c} / \mathbf{a})\end{array}$ \\
\hline \multirow{2}{*}{$\mathbf{2 2 5}$} & $1 \mathrm{~min}$ & $1.3918 \pm 0.0000$ & $1.3814 \pm 0.0000$ & $1.3932 \pm 0.0001$ & - \\
\cline { 2 - 6 } & $3 \mathrm{~min}$ & $1.3918 \pm 0.0000$ & $1.3814 \pm 0.0000$ & $1.3933 \pm 0.0001$ & $1.3996 \pm 0.0004$ \\
\cline { 2 - 6 } & $6 \mathrm{~min}$ & $1.3918 \pm 0.0000$ & $1.3814 \pm 0.0000$ & $1.3932 \pm 0.0002$ & $1.4000 \pm 0.0000$ \\
\hline
\end{tabular}

